\title{
SIBU and the crisis of water service delivery in Sannieshof, North West Province
}

\author{
C GOUWS, I MOEKETSI, S MOTLOUNG, J TEMPELHOFF, G VAN GREUNING AND L VAN \\ $Z Y L^{*}$
}

\begin{abstract}
In 2007 the residents of the town of Sannieshof in North West Province declared a dispute with the Tswaing Local Municipality on the grounds that the state of local service delivery left much to be desired. The ratepayers then formed the Sannieshof Inwoners Belastingbetalers Unie (SIBU) which literally took over the functions of local government of the town, functioning as a local government within a local government.

This article provides a historical narrative of the conflict between SIBU and Tswaing Local Municipality, a dispute which was taken as far as the provincial High Court. Then follows an outline of conditions in Sannieshof and the townships of Agisanang and Phelindaba. Attention is given to the perceptions of local residents on the prevalent conditions, specifically in respect of water supply and sanitation service delivery. In the third section there are some theoretical perspectives on political culture, socialisation and happiness. A debate is provided on how these phenomena manifest under existing conditions in Sannieshof, and more particularly, in its adjacent townships of Agisanang and Phelindaba.
\end{abstract}

Keywords: Sannieshof Inwoners Belastingbetalers Unie (SIBU), North West Province, service delivery, water supply, sanitation, Tswaing Local Municipality.

Disciplines: History, Political Science, Tourism Studies and Public Management and Administration, Industrial Psychology and Wellness Studies.

\section{Introduction}

In November 2007, irate ratepayers of the towns Sannieshof, Ottosdal and Delareyville in South Africa's North West Province, declared a dispute with Tswaing Local Municipality, the local authority responsible for their municipal services. ${ }^{1}$ Using the Municipal Finance (Management) Act, 56 of $2003,{ }^{2}$ the Municipal Structures Act, 117 of 1998, ${ }^{3}$ and the Municipal Systems Act, 32

Research Niche Area for the Cultural Dynamics of Water (CuDyWat). At the time when the report was compiled C Gouws, I Moeketsi, S Motloung and G van Greuning were postgraduate students in CuDyWat. Llewellyn van Zyl, an industrial psychologist, was a member of staff in the School for of Behavioural Sciences, NWU (Vaal). Johann Tempelhoff is the leader of CuDyWat. The reading of this text can be enhanced when it coincides with listening to Larry Coryell's recording of "Redwing" on the CD I'll be over you, (Cti Records, December 1994).

1. C Visser, “'n Jaar in aksie” in SIBU Nuusblad, November 2008, p. 1.

2. Republic of South Africa (RSA), Municipal Finance Management Act, 56 of 2003, in Government Gazette of the Republic of South Africa, Vol. 464 No. 26019, 2004.02.13, pp. 1-18.

3. RSA, Local government: Municipal Structures Act, No. 117 of 1998, in Government Gazette of the Republic of South Africa, Vol. 42 No 19614, 1998.12.18, pp. 1-120.

TD The Journal for Transdisciplinary Research in Southern Africa, 6(1) July 2010, pp. 25-56. 
of $2000,{ }^{4}$ they explained that they had collectively decided to no longer pay municipal rates and taxes. Instead, it was their intention to deposit the monies they would have paid into a separate account. Their motivation for this decision was simple: while residents had continued to pay their rates and taxes the local municipality (Tswaing) did not respond appropriately by delivering adequate municipal services. ${ }^{5}$

At the time there were numerous similar initiatives by ratepayers in various parts of South Africa. What made the ratepayers stand out, particularly those in the town of Sannieshof, was the proactive manner in which they operated. Working at first under the auspices of the Sannieshof Sakekamer, an affiliate of the Afrikaanse Handelsinstituut (AHI), they soon transformed themselves into the Sannieshof Inwoners Belastingbetalers Unie (SIBU) under the leadership of Ms Carin Visser. Visser, a housewife and local entrepreneur, played a prominent role as an assertive leader who was able to motivate local residents to stand together to get things done. To strengthen its hand SIBU also had strong links with the National Taxpayers Union (NTU), an organisation of ratepayers that has been active throughout South Africa since the mid-1990s. ${ }^{6}$ When SIBU was formed in April 2008, local farmers, business people and also some residents of Agisanang, the former apartheid-era township of Sannieshof, were firmly behind the new organisation.

Soon there were rumours about a 'Sannieshof Raad', working to improve the living conditions of all local residents. ${ }^{7}$ Their intention was to form a local municipality within a municipality. Sannieshofs ratepayers had clearly suffered their share of poor municipal service delivery. Indeed, in many parts of the country, especially in the rural areas, residents of small towns have experienced (and are still experiencing) constant frustration. Municipal service delivery has been dismal; by 2009 there was growing consensus that municipal governance is the weakest tier of government in South Africa. ${ }^{8}$ This dubious status came at a price. In 2009 there were a record number of municipal service delivery protests in all parts of the country. ${ }^{9}$ These outbursts appeared to be the culmination of a culture of protest by civil society; society was articulating its disapproval of a rapidly deteriorating system of local government that became apparent in $2004-$ a full decade after the country had been transformed from an apartheid state into a multiracial democratic society.

4. RSA, The Municipal Systems Act, No. 32 of 2000, in Government Gazette of the Republic of South Africa, Vol. 425, No. 21776, 2000.11.20, pp. 1-120.

5. SIBU Electronic Archive (SEA), Correspondence: Taxpayers of Sannieshof, Delareyville and Ottosdal: declaration of dispute. C Visser, D Mare, M van Wyk (Sannieshof), M van der Merwe, N Mengel (Delareyville), M Coetzee, M Pretorius (Ottosdal) - D Legoete, Delareyville, 2007.11.22.

6. E-mail correspondence; J Kelder, Kempton Park - JWN Tempelhoff, 2009.09.13. Attachment: Anon., "Kort oorsig van die organisasie", dated January 2007.

7. Anon., "Sannieshof stig 'n inwonersvereniging" in Noordwester, 2008.03.07, p. 4.

8. Associated Press, "Protests turn violent in South Africa" in The New York Times, 2009.10.15 (Internet accessed 2009.10.15).

9. Municipal IQ Briefing \#153, 2009.09.04, "Service delivery update: what makes 2009 different?” 
Overseas media networks carried reports to the effect that the protests of 2009 were reminiscent of South Africa's anti-apartheid townships in the 1970s and 1980s. ${ }^{10}$ The major difference was that the protests of 2009 were inspired by bread-and-butter politics and perhaps more tellingly, a growing sense of class differentiation within the confines of South Africa's black population. ${ }^{11}$ Working from the perspective of Ockham's razor, analysts ascribed the season of protest to: leadership re-configurations within the ruling African National Congress (ANC)-alliance ${ }^{12}$ following the takeover by President Jacob Zuma in May 2009; ${ }^{13}$ disillusionment with the government's unfulfilled promises $;{ }^{14}$ congestion in the country's towns and cities as a direct result of increased urbanisation from rural areas and neighbouring states and the inability to absorb these; ${ }^{15}$ and the effects of the global recession on the South African economy. ${ }^{16}$

The Sannieshof action by SIBU was different from mainstream service delivery protests in South Africa. Such protest action usually came from irate residents of former apartheid-era black townships and informal settlements. The Sannieshof action was a boycott, driven primarily by members of the white community. Their activities were consistently proactive in that as members of civil society they claimed that they were taking the measures to 'stop the rot'. The central government, formed under the presidency of Jacob Zuma in May 2009, was more than aware of this state of affairs. It was also intent on setting things right. ${ }^{17}$

10. B Bearak, "South Africa's poor renew a tradition of protest" in The New York Times, 2009.09.06 (Internet accessed 2009.09.06 and 2009.10.13); D Smith, "Anger at ANC record boils over in South African townships" in Guardian.co.uk, 2009.07.22 (Internet accessed 2009.10.13); AD Smith, "Zuma pleads as protests sweep the townships" in Guardian.co.uk, 2009.07.26 (Internet accessed 2009.10.13); J Clayton, Foreigners flee as violence reignites in South African townships" in Timesonline.co.uk, 2009.07.25 (Internet accessed 2009.10.14).

11. M Mbeki, "Why are the people rebelling against the ANC government?" in Nedgroup Securities: Flash Note Politics, 2009.10.15, pp. 1-4.

12. Anon, "ANC looks internally for service delivery protest plotters" in SABC News, 2009.09.06 at (Internet accessed 2009.10.13); J Dlamini, "Protesting to join the queue for the gravy train" in Business Day, 2009.08.22 at (Internet accessed 2009.10.13).

13. W-M Gumede, "ANC at war with itself: Zuma walks politically risky tightrope" in Sowetan, 2009.09.23 (Internet accessed 2009.10.13).

14. Anon., "Machadodorp protest spills over to nearby town" in SABC News, 2009.10.13 (Internet accessed 2009.10.13); N Seleka, "Vaal service delivery protest turns ugly" in Sowetan, 2009.09.11 (Internet accessed 2009.10.13); A Hlongwane, M Laganparsad and Z George, "Rash pledges foment unrest" in The Times, 2009.07.27 (Internet accessed 2009.10.14).

15. C Smith, "Economy trumps politics: Sexwale" in Fin24, 2009.0923 at (Internet accessed 2009.10.20); F Smit, “Arm ken nie ras of geslag” in Beeld, 2009.10.16 (Internet accessed 2009.10.16); K Heese and K Allen, "Reading the figures in the flames to find the future of protest" in Business Day, 2009.08.24 (Internet accessed 2009.10.20).

16. B Bearak, "South Africa's poor renew a tradition of protest" in The New York Times, 2009.09.06 (Internet accessed 2009.09.06); Associated Press, "S African police fire rubber bullets on protestors" in The New York Times, 2009.10.13 (Internet accessed 2009.10.13); AFP, “Angry Sakhile residents demand Zuma's attention" in Mail \& Guardian, 2009.10.16 (Internet accessed 2009.10.16).

17. Anon., "The new cabinet's to-do list” in Cape Argus, 2009.05.18 (Internet accessed 2010.05.20). 


\section{Outline}

In this discussion attention will be given to a historical overview of the conflict between SIBU and Tswaing Local Municipality up to September 2009. The focus is specifically on the discontent of local residents with water service delivery. Attention will then focus in on the observations of a North-West University (NWU) research team that conducted fieldwork in Sannieshof and surroundings to investigate the claims of local residents. The views of residents are articulated in terms of the quality of their potable water supplies and the condition of the local sanitation infrastructure. In the third section of the study there is a discussion on the dynamics of the local political culture and its potential to be transformed into a more cohesive civil action. Attention is also given to observations on the theoretical construct of 'happiness' and whether local residents can be said to experience this quality of life.

\section{SIBU garners support}

After they declared the dispute with Tswaing Local Municipality in 2007, local support for the ratepayers' initiative in Sannieshof did not come overnight. Although early indications were that more than 50 per cent of the town's residents were in favour of the boycott action, active resident involvement was at first not forthcoming. It seems local people took a wait-and-see stance. At first, in November-December 2007, only 27 per cent of Sannieshof s residents joined. However, when it became evident how quickly and efficiently Visser and her management team were able to make progress with the town's water problems, there was a marked increase in support. By April 2008 an estimated 60 per cent of the town's residents were paying their monthly municipal rates and taxes to the ratepayers' initiative. ${ }^{18}$ Furthermore, in the townships of Agisanang and Phelindaba Mr Danny Boko, leader of a group of concerned residents of Agisanang, openly came out supporting the initiative. Boko told the media that human waste was lying in the streets of the township. At the local informal settlement there were no toilets - not even buckets. People had to walk several kilometres to reach a tap with drinking water. ${ }^{19}$

SIBU's name soon featured in the Johannesburg daily newspaper Beeld, in an article by the commentator Willem Landman; he referred to a 'parallel municipality' that had been created in Sannieshof. It was clear that there were local moves afoot to take over the management tasks that Tswaing Local Municipality was not performing. Landman was of the opinion that:

The lesson of Sannieshof is that complaints and an attitude of standing with the hands on the hips lead you nowhere. Conditions in many towns have deteriorated to the extent that taxpayers are forced to take up the cudgels themselves. ${ }^{20}$

18. J Eybers, "Sannieshof staan op uit sak en as en stank: raad sê niks ná inwoners dorp regruk" in Rapport, 2008.04.13, p. 10.

19. L de Beer, "Belastingboikot: dorp wil nou sélf dienste koop" in Beeld, 2007.12.15 (Internet accessed 2009.07.15).

20. The quote is translated from the Afrikaans: Die les van Sannieshof is dat 'n gekla en hande-in-die-sy-staan nêrens heen lei nie. Toestande in vele dorpe het sodanig versleg dat belastingbetalers self die hef in die hand sal moet neem. See Willem Landman, "Onbevoegde munisipaliteite mag geSannieshof word" in Beeld, 2008.04.03 (Internet accessed 2009.07.15). 
Confident of their apparent support, SIBU and the Sakekamer collaboratively confronted the Tswaing Local Municipality on the annual budget for 2008-9, which they rejected outright. Residents of Sannieshof, Agisanang and Phelindaba, they argued, had been totally excluded from the planning development process in the region. ${ }^{21}$ Faced by a local municipality whose management stubbornly refused to heed the valid grievances of Sannieshof s residents, Visser decided to pursue a new strategy. Because municipal office-bearers blithely ignored SIBU's official correspondence, ${ }^{22}$ Visser began writing open letters in the regional media to Tswaing's municipal manager, Mr Dakota Legoete. ${ }^{23}$

This was a body blow to the provincial government. In August 2008 a senior ANC provincial leader, Lechesa Tshenoli, said that the party was concerned about the growing ratepayers' discontent with municipal service delivery. ${ }^{24}$ The provincial government singled out Sannieshof s SIBU as symptomatic of growing discontent. Consequently a team of provincial officials was sent in to help Tswaing Municipality with an action plan for improved local service delivery. ${ }^{25}$ Problems were widespread. ${ }^{26}$

SIBU's management continued to apply pressure by repeatedly sending a litany of complaints and statements in official letters and e-mail correspondence to the offices of Tswaing Local Municipality. Water-related problems featured prominently in the list of grievances. Documentation accessed by the research team brought to light that at least 60 per cent of ratepayers' complaints revolved around water services. ${ }^{27}$ For example, there were concerns about: faulty accounts; $;^{28}$ independent laboratory tests reporting on Sannieshof s inferior water quality; ${ }^{29}$ the town's fire brigade being used to transport water to the neighbouring town of Ottosdal/Letsopa $;^{30}$ the non-removal of the town's domestic sewage; ${ }^{31}$ the deteriorating state of

21. SIBU Archive, Correspondence: C Visser, Sannieshof - D Legoete, Delareyville, 2008.05.28.

22. C Visser, Sannieshof - Editor, "So pak Sannieshof dienstekrisis" in Beeld, 2008.07.01, p. 16.

23. C Visser, Sannieshof - D Legoete, Delareyville, "Open letter to the mayor and municipal manager, Tswaing local municipality Delareyville: External service provider Sannieshof” in Noordwester, 2008.06.27, p. 15; C Visser, Sannieshof - D Legoete, Delareyville, in Noordwester, 2008.07.18, p. 8.

24. A Slabbert, "Protes-weerhouding van munisipale dienstegelde kwel ANC" in Sakebeeld, 2008.08.20, p. 2d (Clippings file, Sannieshof Public Library).

25. L de Beer, "Dispuut teen Sannieshof-raad werp al vrugte af" in Beeld, 2008.06.19 (Internet accessed 2009.07.15).

26. L de Beer, "Dispuut teen Sannieshof-raad werp al vrugte af" in Beeld, 2008.06.19 (Internet accessed 2009.07.15).

27. Anon., "Inwoners van drie dorpe op agtervoete: Sannieshof, Delareyville en Ottosdal verklaar dispuut" in Noordwester, 2007.11.30, p. 5.

28. SEA, Correspondence: C Visser - D Morwe, Sannieshof, 2008.03.13; C Visser - D Legoete, 2008.03.25; C Visser - D Morwe, 2008.06.17; C Visser, Sannieshof - W Horn, 2009.09.12; E-mail: C Visser - I O’Neill, BCX Data, Pta, 2009.02.25; E-mail: C Visser - D Legoete, 2008.09.24;

29. SEA, E-mail and attachment: C Visser - D Legoete, 2009.05.14; Test report, Midvaal Water Company, Scientific services, 2009.04.24.

30 . SEA, E-mail correspondence: C Visser - H Breytenbach, 2009.11.20.

31. SEA, E-mail correspondence: C Visser - H Breytenbach, 2008.06.19; C Visser - H Breytenbach, 2008.10.22; C Visser - H Breytenbach, 2009.01.23; . 
the town's streets and the need to remove refuse; ${ }^{32}$ municipal officials not doing their work properly; $;^{33}$ breakdowns in the town's water supply; ${ }^{34}$ municipal boreholes out of order; ${ }^{35}$ the contestation of a decision by Tswaing's management to address the water crisis in Ottosdal and Delareyville before giving attention to the problems in Sannieshof; ${ }^{36}$ problems at the municipal refuse dumpsite; ${ }^{37}$ blocked municipal storm water drains; $;^{38}$ the town's water plight; ${ }^{39}$ diverse water leaks; ${ }^{40}$ and the installation of pre-paid electricity meter boxes. ${ }^{41}$

In March 2009, when Visser gave an overview of SIBU and the Sakekamer's activities, ${ }^{42}$ she was convinced of the success of their 16-month-old initiative:

We are fighting for the maintenance of quality of life. For that reason we are withholding our payments for property tax, refuse and sewage removal and water. We only pay for electricity. ${ }^{43}$

At the time the ratepayers' boycott was supported by 70 per cent of Sannieshof s residents. ${ }^{44}$ The residents' initiative had proved its resilience and ability to set things right. SIBU's workers had repaired broken water systems; cleaned up the town; and upgraded the town's waste disposal site. In addition they had employed four workers and also paid some of Tswaing Local Municiplality's outstanding accounts. In total this had cost the ratepayers R163 $000 .{ }^{45}$

The councillors and officials of Tswaing Local Municipality were clearly dissatisfied with the state of affairs. By May 2009, when Sannieshof s rates and taxes were R21,7 million in arrears, the municipality appointed a Potchefstroom attorney, Mr Eric Louw, to take legal steps against

32. SEA, E-mail correspondence: C Visser - H Breytenbach, 2008.06.30; E-mail: C Visser - H Breytenbach, 2008.08.03.

33. SEA, E-mail correspondence: C Visser - H Breytenbach, 2008.08.05.

34. SEA, E-mail correspondence: C Visser - H Breytenbach, 2008.09.15.

35. SEA, E-mail correspondence: C Visser - H Breytenbach, 2008.09.15; E-mail correspondence: C Visser H Breytenbach, 2008.09.21.

36. SEA, E-mail correspondence: C Visser - H Breytenbach, 2008.09.26.

37 . SEA, E-mail correspondence: C Visser - H Breytenbach, 2008.09.28.

38. SEA, E-mail correspondence: C Visser - H Breytenbach, 2008.09.30; C Visser - H Breytenbach, 2009.02.24.

39. SEA, E-mail correspondence: C Visser - H Breytenbach, 2008.10.11; C Visser - H Breytenbach, 2008.10.17; C Visser - H Breytenbach, 2009,01.07;

40 . SEA, E-mail correspondence: C Visser - H Breytenbach, 2008.10.08.

41. SEA, Correspondence: C Visser - H Breytenbach, 2009.02.16.

42. See SIBU Archive, C Visser, Status quo report of conditions in Sannieshof, 17 March 2009, as presented to the department of local government and housing.

43. Translated from the Afrikaans: Ons baklei vir die behoud van lewensgehalte. Daarom hou ons ons geld vir eiendomsbelasting, vullis-, en rioolverwydering en water terug. Ons betaal slegs vir elektrisiteit. in N van der Walt, "Bankvas agter dispuut" in Beeld, 2009.03.13 Internet accessed 2009.07.15).

44. N van der Walt, "Bankvas agter dispuut” in Beeld, 2009.03.13 (Internet accessed 2009.07.15).

45. N van der Walt, "Bankvas agter dispuut" in Beeld, 2009.03.13 (Internet accessed 2009.07.15). 
about 500 ratepayers who were in arrears. Not all were members of SIBU which at the time had about 300 members. Furthermore, the other formerly white towns that fell under the Tswaing municipal area (Delareyville and Ottosdal), owed the local municipality R27,2 million and R46,7 million respectively. ${ }^{46}$

When Tswaing Municipality announced that it was suing the ratepayers, the battle lines were drawn over a much larger front. The National Taxpayers Union described Sannieshof as 'a showpiece of civil action' and assured the media that the NTU stood firmly behind SIBU. Its national partner, the NTU, was confident that Sannieshof's residents had a strong case. ${ }^{47}$

The first salvo in the legal battle was symbolically fired on 18 May 2009 when at Sannieshof's sewerage works, a Tswaing municipal official threatened SIBU chairperson, Visser, in the presence of the police, that she would be prosecuted for trespassing on municipal property. ${ }^{48}$ She explained that it was essential for her and members of her team to work on the wastewater treatment works to prevent raw sewage from flowing into the nearby Harts River. ${ }^{49}$ Nothing came of this first confrontation.

Visser and her management committee had done considerable homework beforehand to determine precisely what had to be done in an attempt to restore the local wastewater treatment works. ${ }^{50}$ The plant had not been properly maintained since being taken into use in $1999 .{ }^{51}$ SIBU's members were determined to carry out their plans. They had already spent R45 000 on purchasing a pump to extract sewage from clogged systems at the plant. A further R20 000 had been spent on servicing a broken sewage pump in Agisanang township. ${ }^{52}$ Meanwhile sewage was freely flowing into the nearby Harts River. This state of affairs severely affected the environment of the internationally listed RAMSAR wetland site of Barberspan wetlands and nature reserve. ${ }^{53}$

46. L de Beer, "Weerhou van geld aan raad in hof getoets" in Beeld, 2009.05.01 (Internet accessed 2009.07.16).

47. L de Beer, "Weerhou van geld aan raad in hof getoets" in Beeld, 2009.05.01 (Internet accessed 2009.07.16).

48. A Slabbert, "Sannieshofse Sannie dalk in hof oor riool" in Sakebeeld, 2009.05.26 (Sannieshof Municipal Library Newspaper clippings file); Verslaggewer, "Sannieshof se inwoners geïntimideer" in Praag.co.za, 2009.05.20 (Internet accessed 2009.10.15).

49. L de Beer, "Sannieshoffers help lid in hof wat eiendomsbelasting weerhou" in Beeld, 2009.06.04, p. 6; Anon., "Aanklaer weier vervolging" in Die Noordwester, 2009.06.05, pp. 1 and 2.

50. Anon., "Rehabilitasie by die rioolwerke" in Die Noordwester, 2009.05.22. (Sannieshof Municipal Library Newspaper clippings file).

51. TJOA, Interview: JC Swanepoel, Sannieshof Hotel, 2009.09.01.

52. L de Beer, "Sannieshoffers help lid in hof wat eiendomsbelasting weerhou" in Beeld, 2009.06.04, p. 6; Anon., "Aanklaer weier vervolging" in Die Noordwester, 2009.06.05, pp. 1 and 2.

53. See South African Wetlands Conservation Programme: DR Swart and GI Cowan, Barberspan: South Africa Information sheet for the site designated to the List of Wetlands of International Importance in terms of the Convention on Wetlands of International Importance especially as Waterfowl Habitat, (1992 and 1994) (Internet accessed 2009.10.15); L de Beer, "Inwoners pak rioolkrisis" in Beeld, 2009.05.19 (Internet accessed 2009.07.16) 
Sannieshof's residents were particularly irate when raw sewage began to flood their properties and run into storm water drains in the town's streets. ${ }^{54}$

On 23 May, when a SIBU team resumed its repair work at the sewerage plant a senior official who had been studying the activities through binoculars, approached the team. Policemen accompanied him. After a verbal confrontation Visser was removed from the site and taken to the police station where a case of trespassing was opened against her and Mr Manie Schutte, another member of the SIBU committee. ${ }^{55}$ However, on 3 June 2009 when Visser and Schutte arrived at the Delareyville magistrate's court for a court appearance, they were informed that the public prosecutor had refused to begin the formal prosecution of SIBU's committee members. It seems he had thrown the case out. ${ }^{56}$ The conflict potential then intensified, with Tswaing Local Municipality taking the matter to the High Court.

\section{In the High Court}

When the High Court case began in Mafikeng on 23 June 2009 about 100 residents of Sannieshof, Agisanang and Phelindaba packed the courtroom over which Judge Adrian Landman presided. ${ }^{57}$ Sannieshof and SIBU in particular, took centre stage in South Africa's news media; the court case was described as unique - the first of its kind..$^{58}$ For all practical purposes Sannieshof had become the benchmark for ratepayers in all parts of the country who had to contend with inferior service delivery. ${ }^{59}$

In the court documents Visser asked that the management of Tswaing Local Municipality be instructed to submit a sustainable development plan for service delivery in Sannieshof. It had to be ready by February 2010 and be in compliance with the requirements of the provincial department of local government. In the meantime, SIBU sought authorisation to continue with the management of local government matters in Sannieshof. ${ }^{60}$ In response Tswaing Local Municipality's Dakota Legoete argued that SIBU was by no means representative of all the residents of Sannieshof. They were but a small group of privileged people trying to undermine the local municipality's service plan. He also contested claims by SIBU that the integrated

54. Anon., "Rehabilitasie by die rioolwerke" in Die Noordwester, 2009.05.22. (Sannieshof Municipal Library, Newspaper clippings file).

55. A Slabbert, "Sannieshofse Sannie dalk in hof oor riool" in Sakebeeld, 2009.05.26 (Sannieshof Municipal Library Newspaper clippings file); L de Beer, "Sannieshoffers help lid in hof wat eiendomsbelasting weerhou" in Beeld, 2009.06.04, p. 6.

56. L de Beer, "Sannieshoffers help lid in hof wat eiendomsbelasting weerhou" in Beeld, 2009.06.04, p. 6.Anon., "Aanklaer weier vervolking" in Noordwester, 2009.06.05, pp. 1 and 2.

57. L de Beer, "Sannieshof-saak uitgestel weens regstegniese punt" in Beeld, 2009.06.23 (Internet accessed 2009.09.06).

58. Ibid. ; K Foss, "Sewage in the streets - residents up in arms" in The Star, 2009.06.24, p. 2.

59. W Landman, "Tswaing probeer bolle as vye aan Sannieshof verkoop" in Fin24.com, 2009.07.16 (Internet accessed on 2009.10.14).

60. A Slabbert, “'Bevoorregtes kelder Tswaing se diensplan”” in Rapport, 2009.06.21. (Sannieshof Municipal Library: Newspaper clippings file). A Slabbert, "Daar's oorlog in Sannieshof” in Fin24.com, 2009.06.27 (Internet accessed 2009.09.06). 
development plan (IDP) of Tswaing was in a state of chaos. ${ }^{61}$ Then, in a technical move, Tswaing's lawyers asked the judge to call in other concerned parties, such as representatives of the district municipality of Ngaka Modiri Molema; the MEC of North West Province responsible for local government; as well as the province's premier. ${ }^{62}$ The MEC did not appear in court, but the executive mayor of Ngaka Modiri Molema district municipality, Themba Gwabeni, was there. In his statement he explained that the people who were opting to deposit their rates and taxes in a private account were in fact contributing to the problem:

\section{They come to court to complain that there are no services when actually they are accessories in making sure no services are delivered. ${ }^{63}$}

Outside the courtroom, people speculated that Tswaing Local Municipality's legal team had been using delaying tactics aimed at winning time. Tswaing's municipal manager, Legoete, argued that making concessions for the 'civil disobedience' of the Sannieshof ratepayers was a 'recipe for anarchy'. ${ }^{64}$ Shortly afterwards the case was postponed.

When the case resumed, Judge Landman, in his judgement, pointed out that the residents of a municipality had been called upon to take an active interest in the matters of their council. However, in respect of matters where the council refuted their participation, they had to specify the foundation on which they demanded participation. They also had to support the precise nature of the rights they asked of the court. ${ }^{65}$ Although the High Court rejected SIBU's application, ${ }^{66}$ the ratepayers were not instructed to pay the legal fees. Tswaing Local Municipality had to pay R300 000. ${ }^{67}$ Ultimately the losers were the ratepayers of Tswaing Local Municipality who, indirectly, had to foot the bill. SIBU benefited from the state of affairs.

The ratepayers' organisation summarily carried on with its actions against poor service delivery. At the same time Mr Jaap Kelder of the National Taxpayers Union NTU let it be known that the organisation was preparing itself to take the matter further. He said more than 200 towns in all parts of South Africa were ready to join the protest against poor service delivery. ${ }^{68}$

Tswaing Local Municipality's technical director, Mr Hennie Breytenbach, responded to some of the reports that had appeared on the website of Praag, a rightwing-inspired non-governmental organisation. Officials, management and some external observers had for long been of the

61. SEA, High Court application, Case 1498/09 in the North West High Court, Mafeking, 2009.06.23; A Slabbert, "Daar's oorlog in Sannieshof" in Fin24.com, 2009.06.27 (Internet accessed 2009.09.06).

62. L de Beer, "Sannieshof-saak uitgestel weens regstegniese punt" in Beeld, 2009.06.23 (Internet accessed 2009.09.06).

63. K Foss, "Sewage in the streets - residents up in arms" in The Star, 2009.06.24, p. 2.

64. L de Beer, "Sannieshof-saak uitgestel weens regstegniese punt" in Beeld, 2009.06.24 (Sannieshof Library: Newspaper clippings file).

65. A Slabbert, "Wetlose Sannieshof kannie hof oortuig" in Sake 24, 2009.07.30 (Internet accessed 2009.09.06).

66. L de Beer, “Zuma’s office praised” in News24, 2009.06.30 (Internet accessed 2009.09.06).

67. A Slabbert, "Daar's oorlog in Sannieshof” in Fin24.com, 2009.06.27 (Internet accessed 2009.09.06).

68. A Slabbert, "Daar's oorlog in Sannieshof" in Fin24.com, 2009.06.27 (Internet accessed 2009.09.06). 
opinion that the Sannieshof boycott had strong rightwing leanings. This probably motivated Breytenbach to give his interpretation of the Sannieshof issue on the Praag website. He explained that most of the problems with service delivery had arisen before he took over as technical director in May 2008. He also pointed to other issues that had caused the breach between the municipality and the ratepayers. ${ }^{69}$ His defence did not achieve its objective. SIBU's Visser promptly responded to some of the more obvious gaps in his statements, ${ }^{70}$ undermining his attempts to convey a convincing argument.

The most meaningful consequence of the court case was that Sannieshof and its residents became celebrities of sorts. Ordinary folk in South Africa, including officials in several government departments, began to sit up and take note of Sannieshof s SIBU. This was evident when Carin Visser communicated with the office of President Zuma shortly after the court case. Staff there requested that she submit documentation with information on the state of municipal service delivery in Sannieshof, Agisanang and Phelindaba. Visser later told the media she was pleasantly surprised by the immediate response she had received. It was the quickest response she as leader of SIBU had ever had from any government department. ${ }^{71}$ It later transpired that Visser's call was one of the very early appeals on the presidential telephonic hotline. This had not only paved the way for more efficient channels of communication between the ratepayers of Sannieshof and surroundings and the North West Province's department of traditional and municipal government, but also eased the path to the relevant national government departments. Indeed, the government received praise in the public realm for its response to SIBU. ${ }^{72}$

\section{Government takes action}

At the beginning of July 2009, the new North West Province premier, Maureen Modiselle, placed the Ngaka Modiri Molema District Municipality (the municipality in which Tswaing Local Municipality falls), under provisional administration. It became apparent that while service delivery in the central district of North West Province was lagging behind, there was R83 million in the municipal coffers that had not been spent. Cooperative governance and traditional affairs minister, Sichelo Sicheka, was angered by this state of affairs, announcing that in fact it would only require R63 million to remedy the situation and provide sufficient service delivery in the municipal district. ${ }^{73}$ By mid-August the district municipality's officials and legal team were in a desperate battle to restore the legal status of the municipality. ${ }^{74}$ In the process, the provincial government dismissed the mayor, Themba Gwabeni. ${ }^{75}$ There were however other problems looming.

69. H Breytenbach, "Sannieshof-amptenaar antwoord op kritiek" in Praag.co.za, 2009.06.20 (Internet accessed 2009.10.16).

70. Ibid.

71. L de Beer, “Zuma’s office praised” in News24, 2009.06.30 (Internet accessed 2009.09.06).

72. Editorial comment: "Munisipale ingryping net betyds" in Volksblad, 2009.0716 (Internet accessed 2009.10.16).

73. Sapa, "R83m in municipality's coffers" in News24, 2009.08.05 (Internet accessed 2009.10.16).

74. L de Beer, "Premier, minister, LUR, vra nog tyd in saak oor munisipale magte" in Beeld, 2009.08.13 (Internet accessed 2009.10.16).

75. L de Beer, “ANC onthef 1ste burger uit amp” in Beeld, 2009.08.20 (Internet accessed 2009.10.16). 
In August 2009 a confidential ANC report was leaked to the media. It suggested that all 25 municipalities in the North West Province were literally teetering on the brink of collapse. ANC leaders blamed infighting for this state of affairs. Of significance in the media reports was the worrisome reference to dwindling finances:

\section{The financial status of many of the local and district municipalities is so serious that a number are on the verge of bankruptcy. ${ }^{76}$}

The ANC leadership told the media that steps would be taken against members in responsible positions who were guilty of nepotism and irregular staff appointments; inflating and awarding tenders to companies that funded political campaigns; accepting bribes and kickbacks from service providers; abusing council credit cards, vehicles and property; and selling council property. ${ }^{77}$ The report also suggested that such problems presented a mounting crisis in municipal service delivery in the entire province. ${ }^{78}$

On 3 September 2009, North West Province's local government and traditional affairs MEC, Mothibedi Kegakilwe, held a meeting with officials of Tswaing Local Municipality; Ngaka Modiri District Municipality; and representatives of the ratepayers of Sannieshof, Ottosdal and Delareyville. He told the meeting that President Jacob Zuma had asked provincial premier, Maureen Modiselle, to pay particular attention to the service delivery problems in Tswaing Local Municipality. He wanted to see the problems in Tswaing addressed as a priority; the provincial government was asked to render assistance. ${ }^{79}$

Kegakilwe had clearly done his homework beforehand. Officials of the district municipality told the meeting how R53 million of the district's funds were earmarked for spending in the current book year to pay for critical interventions to improve the water infrastructure. At the end of the meeting the MEC suggested to the ratepayers' representatives that in view of the fact that matters were being set right, residents of Sannieshof, Delareyville and Ottosdal should resume paying rates to the local municipality. SIBU's Visser, as well as the representatives of the other towns, did not agree. They told Kegakilwe there were still far too many issues that required attention; these would have to be addressed before they could end their collective dispute. ${ }^{80}$ In other words, the SIBU boycott action remained in place.

\section{Findings: conditions in Sannieshof, Agisanang and Phelindaba}

In August-September 2009 a research team of North-West University's CuDyWat conducted research fieldwork at Sannieshof to make an assessment of local conditions and gather information on stakeholders' perspectives. The group conducted oral interviews with local

76. X Mbanjwa, "ANC infighting brings municipalities to their knees" in Sunday Independent, 2009.08.23, p. 1.

77. X Mbanjwa, "ANC infighting brings municipalities to their knees" in Sunday Independent, 2009.08.23, p. 1.

78. P du Toit, "Provinsie op sy knieë” in Die Burger, 2009.08.31 (Archive SIBU).

79. TJOA, Minutes of meeting, 2009.09.03, Delareyville Municipal offices; MIOA, Notes of meeting Delareyville, 2009.09.03.

80. TJOA, Minutes of meeting, 2009.09.03, Delareyville Municipal offices; MIOA, Notes of meeting Delareyville, 2009.09.03. 
residents and officials. A digital archive was compiled to record the findings, which comprised inter alia notes taken at interviews; photographic material, electronic and hard copies of documents made available by SIBU and the Tswaing Local Municipality; and relevant secondary source material. In order to protect the identity of respondents the researchers codified their names. ${ }^{81}$ The preliminary report was shared with all stakeholders in a transparent manner in November 2009 at a public meeting where all were asked to comment and advise the team on additions or changes that needed to be made to the report. These changes were duly made and in November 2009 the report was released to all parties concerned. ${ }^{82}$

\section{Domestic water supply}

The investigation by the research team brought to light that the residents of Sannieshof, as a result of SIBU's role, had managed to take control of the town's water supply management. The organisation's members identified leaks in the mains and then took steps to repair them. There also appeared to be other serious problems. Residents told the researchers that the local reservoirs had not been cleaned or flushed in 20 years. This could well have been a factor contributing to the poor quality of the town's drinking water in September $2009 .{ }^{83}$ There were significant water leaks, leading to excessive wastage, at some of the boreholes in the Harts River wetland where the town's water supply was pumped up to reservoirs. ${ }^{84}$ The telemetric system that controlled the pumps had been damaged by ESCOM's power outages in 2008 and had not yet been repaired by September $2009 .{ }^{85}$

Of greater concern to the ratepayers was the condition of the local wetland. Until the 1970s the wetland had boasted a profusion of reeds, birds and wildlife. ${ }^{86}$ By 2009 there were no reeds, no wildlife and hardly any birdlife. Instead, Sannieshofs refuse dump had been relocated to the wetland area, on the Agisanang side of the river. At the time of the fieldwork, residents were worried that the local water supply had been contaminated; they believed that the contamination was not in the groundwater per se. ${ }^{87}$ The summer rainy season usually allowed polluted storm and floodwater to flow into the wetlands. ${ }^{88}$ Members of SIBU had been on the alert for this. They frequently took samples of the town's boreholes, especially when they became aware of the sewage leaks from the local wastewater treatment plant. SIBU's management had also on

81. Individual electronic research archives were compiled under the names of the researchers, as follows: Claudia Gouws (GCOA), Isaac Moektsi (MIOA), Sysman Motloung (MSOA), Johann Tempelhoff (TJOA), and Gerhard van Greuning (VGOA)

82. C Gouws, I Moeketsi, S Motloung, J Tempelhoff, G van Greuning and L van Zyl, 'I hate it when people don't like me': SIBU and the crisis of water service delivery in Sannieshof, North West Province (NWU, CuDyWat, Report 2/2009, Version 2.8, Vanderbijlpark November 2009).

83. MSOA, Interview 2: 2009.09.01; GCOA, Interview 7: 2009.09.01.

84. Site inspection of boreholes by members of the research team on 2009.09.02.

85. GCOA, Interview 11: 2009.09.02.

86. GCOA, Interview 13: 2009.09.03.

87. GCOA, Interview 11: 2009.09.02.

88. GCOA, Interview 11: 2009.09.02; GCOA, Interview 15: 2009.09.03. 
numerous occasions stated that there were unacceptably high counts of Escherichia coli (E. Coli) at some of the boreholes. ${ }^{89}$



Illustration 1 One of the borehole pumping stations in the wetlands of the Harts River at Sannieshof in September 2009. The site had lots of rubble. The fence was damaged and the pumping house's walls badly cracked. (Photograph JWN Tempelhoff)

Some residents of Sannieshof resorted to buying bottled water. ${ }^{90}$ In September 2009 it sold in town for R15 per $5 l$ at a local grocer and R1 per litre at a dedicated water retail outlet, Fresh Water, in the main street. ${ }^{11}$ Some of the town's residents installed filters to domestic taps used for human consumption..$^{92}$ The borehole water of some residential properties in Sannieshof was also contaminated. Residents assumed it to be due to old leaking septic tanks. ${ }^{93}$ People living in the so-called 'onder dorp' (lower part) of town experienced problems with what was said to be diesel in their borehole water. They claimed that their borehole water was 'useless'. ${ }^{94}$ While the residential area of Sannieshof, on the whole, appeared to be fairly well-managed in terms of water services, the same could not be said of conditions in the former apartheid-era township of Agisanang and its informal settlement, Phelindaba.

89. GCOA, Interview 11: 2009.09.02; GCOA, Interview 15: 2009.09.03.

90. GCOA, Interview 16: 2009.09.03.

91. TJOA, Interview 2: 2009.09.01; TJOA, Interview 7: 2009.09.03.

92. TJOA, Interview 2: 2009.09.01.

93. GCOA, Interview 12: 2009.09.02.

94. TJOA, Interview 6: 2009.09.03. 




Illustration 2 A resident of Phelindaba breastfeeds an infant and patiently waits for her turn to take water from the public tap at Phelindaba. (Photograph: C Gouws)

In September 2009 the water infrastructure was varied in Agisanang, Sections 1, 2 and 3 (Phelindaba). Agisanang Extension 1, the old township, was established in the 1950s to accommodate local migrant workers from the nearby former homeland area of Bophuthatswana. The houses were designed as temporary dwellings on the assumption that the workers would return to the homeland once their work contracts expired. In the old houses there were no running water taps or flushing toilets. After 1994, each residential stand of Agisanang was provided with a tap and outside flush toilet. Agisanang Extension 2 was established after 1994 when in terms of the government's Reconstruction and Development Program (RDP), homes were built for township residents who did not have ready access to housing. When these were built they were provided with the basic infrastructure for water supply and sanitation. Agisanang Extension 3 (also known as Phelindaba) is an informal settlement. Literally hundreds of people streamed into the area since the 1990s, in response to the government's promise of free housing. ${ }^{95}$

Many of the new local residents were previously farm workers who had allegedly been forced off the land by farmers who either wanted to steer clear of land claims issues, or decided to reduce

95. GCOA, Interview 3: 2009.09.01; GCOA, Interview 6: 2009.09.01; MIOA, Interview 4: 2009.09.01; MIOA, Interview 10: 2009.01.03; TJOA, Interview 8: 2009.09.03; TJOA, Interview 4: 2009.09.01; TJOA, Interview 5: 2009.09.02; MSOA, Interview 8: 2009.09.02. 
the size of their labour contingent in the light of the government's changing labour laws. ${ }^{96}$ Some residents of Phelindaba came from the former homeland of Bophuthatswana. They relocated in an effort to be closer to a proper town with potential job opportunities and a commercial trading centre. They were also of the opinion that in Agisanang their prospects of getting housing were far better than in the former homeland. Another category of residents in Phelindaba was a group of people who chose to move from one part of Tswaing Local Municipality to another - as soon as they heard of local councillors promising houses in newly developed townships. Since 1994 it frequently happened that there would literally overnight be a stampede of people and massive overcrowding in the urban areas of Tswaing Local Municipality. More often than not the people's expectations were not met and they would be subjected to living under conditions of dismal poverty in informal settlements. At the time of the fieldwork in September 2009, most of these people, resident in Phelindaba were unemployed and extremely poor. ${ }^{97}$

The local water plight was worst in Phelindaba. There were only three public taps in the informal settlement. Indeed at the time of the research group's visit the water supply of Phelindaba had been reduced to a single tap; the others were out of order. ${ }^{98}$ Local residents told the researchers that municipal officials frequently accused the residents of 'wasting water'. ${ }^{99}$ A female resident of Phelindaba, in sheer frustration and defiance, took the initiative to do repair work on one of the public taps and managed to get it working again. Members of the settlement immediately began using it. The resident who had done the repair work was then taken to task by the local councillor. She was told in no uncertain terms that she had interfered with the work of the municipal officials. ${ }^{100}$

Interviews conducted with Phelindaba residents at the water tap brought to light that if the taps were out of order some residents resorted to going to nearby RDP houses in Agisanang Extension 2 to ask for water - at a cost. There were also rumours that local officials were in cahoots with residents of RDP houses who agreed to share the income from the provision of water to Phelindaba residents. People paid as much as R5 for $25 \ell$ of water. ${ }^{101} \mathrm{~A}$ local businessman told the research team that the poorest of the poor were actually paying more for water than the ratepayers of Sannieshof. Phelindaba residents were well aware of this state of affairs. In interviews they argued that it was proof that the municipality did not care a 'damn' for them. ${ }^{102}$

96. According to Carin Visser there were no proven instances of people being forced off the land by farmers in the vicinity of Sannieshof and environs. She submitted information pointing to land that had been secured for previously disadvantaged people. In addition, there are indications that there may have been irregularities in the allocation of the land. See SEA, Email correspondence: C Visser - JWN Tempelhoff, 2009.11.10.

97. GCOA, Interview 3: 2009.09.01; GCOA, Interview 6: 2009.09.01; MIOA, Interview 4: 2009.09.01; MIOA, Interview 10: 2009.01.03; TJOA, Interview 8: 2009.09.03; TJOA, Interview 4: 2009.09.01; TJOA, Interview 5: 2009.09.02; MSOA, Interview 8: 2009.09.02.

98. At the time of our first visit, two of the three communal taps in this settlement were out of order.

99. GCOA, Interview 8: 2009.09.01.

100. MSOA, Interview 3: 2009.09.01; TJOA, Interview 7: 2009.09.03.

101. GCOA, Interview 3: 2009.09.01; MIOA, Interview 9: 2009.09.02; MIOA, Interview 10: 2009.09.02.

102. MIOA, Interview 2: 2009.09.01. 


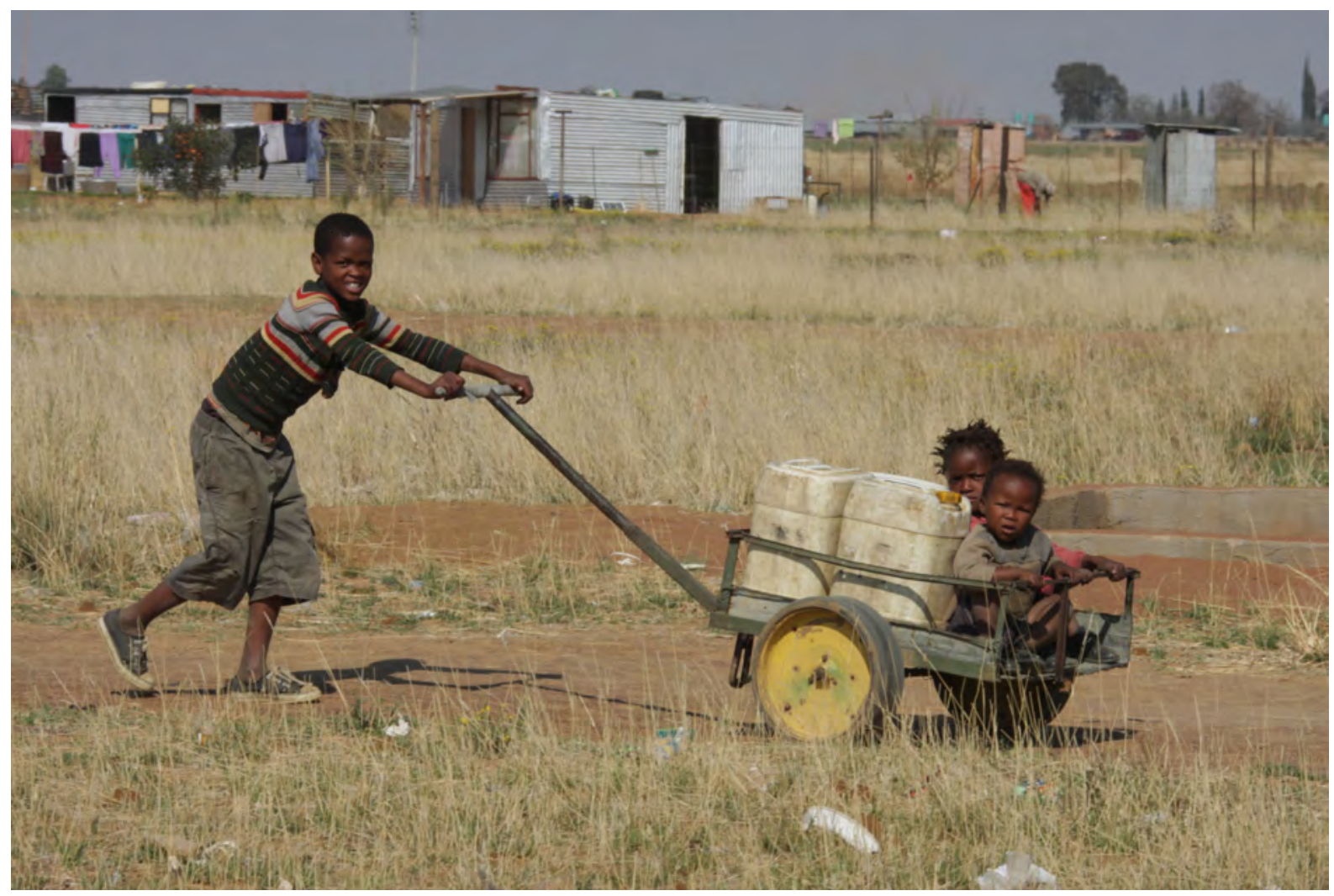

Illustration 3 A youth with siblings and a water cart on the way to the public taps of Phelindaba informal settlement. (Photograph: JWN Tempelhoff)

In other parts of Agisanang the provision of water was marginally better. However, there were still many problems. Since 2000, when legislation was passed to this effect, all households in the country have enjoyed the basic right to $6 \mathrm{Kl}$ of free water. This is generally assumed to be an adequate monthly supply for a typical previously disadvantaged household in South Africa. The understanding is that when households consume more, they have to pay for it. Respondents told the researchers that the municipality charged them for water, yet there were no meters installed on their properties. ${ }^{103}$ The state of affairs in September 2009 was in effect administrative chaos at the municipal office; local residents simply did not pay for water. ${ }^{104}$ It seemed as if no one really cared about how much water was being consumed by households. ${ }^{105}$ One local resident said:

We use water without taking count of volume; it is something we don't consider in the township. ${ }^{106}$

At times the local Tirisano High School acted as the only source of water for the residents at the nearby informal settlement. ${ }^{107}$ The school tried to open a water account at the municipality for

103. GCOA, Interview 6: 2009.09.01.

104. GCOA, Interview 2: 2009.09.01; GCOA, Interview 5: 2009.09.01; GCOA, Interview 8: 2009.09.01; MSOA, Interview 7: 2009.09.02.

105. GCOA, Interview 5: 2009.09.01.

106. MIOA, Interview 4: 2009-09-01.

107. GCOA, Interview 5: 2009.09.01. 
two years. Nothing happened. When they communicated again with the municipality on the matter officials told them there was a 'delay in the paper work'; they were told to wait for the bill. ${ }^{108}$ It had not yet reached the school by the end of 2009 .

Ratepayers in Sannieshof were concerned about this parlous state of affairs. It came to their attention at the time of the 2009 elections that candidates standing for political office told residents of Agisanang that no one in the township would have to pay for water. ${ }^{109}$ The Sannieshof residents, in turn argued that clean drinking water was locally in short supply. If residents simply received water free of charge they would not bother to use it sparingly. Furthermore, if the municipality were to introduce water restrictions, these would obviously be a dismal failure in the township.

Residents of Agisanang had other issues. They complained that their drinking water smelt like sewerage. ${ }^{110}$ Sometimes supplies were cut off for up to five days. ${ }^{111}$ The municipality did not bother to notify local residents of the cut-off in advance. ${ }^{12}$ This had far-reaching implications for the daily activities of the community. Children did not attend school. ${ }^{113}$ One teacher explained:

We usually send learners back home because there will not be any water to drink, and the learners will not come to school if the water has not returned the next day, because they cannot wash or eat. ${ }^{114}$

There is no system to effectively close leaking public taps at night, so drinking water is wasted. Residents do not use a great deal of water and yet they spend many hours each day collecting water at the taps, ${ }^{115}$ where they sometimes have to queue for up to four hours to fill their containers. ${ }^{116}$

Members of the research team came to the conclusion that water taken from the public taps was almost certainly dirty before being used for drinking. ${ }^{117}$ Conditions around the tap were seldom, if ever, hygienic. Residents said they tried to boil the water they collected from the tap ${ }^{118}$ but

108. GCOA, Interview 5: 2009.09.01.

109. TJOA, Interview 1: 2009.09.02 and 2009.09.04.

110. GCOA, Interview 1: 2009.09.01.

111. GCOA, Interview 1: 2009.09.01; GCOA, Interview 5: 2009.09.01; GCOA, Interview 11: 2009.09.02.

112. GCOA, Interview 5: 2009.09.01.

113. GCOA, Interview 1: 2009.09.01; GCOA, Interview 5: 2009.09.01; GCOA, Interview 11: 2009.09.02.

114. GCOA, Interview 5: 2009.09.01.

115. The aim of the White Paper on water and sanitation, released in November 1994, was to supply clean drinking water and sanitation to all households in SA and to provide 20-30 $\ell$ of water per capita per day within a radius of $200 \mathrm{~m}$ of their homes. JWN Tempelhoff, "Service delivery conflict in South Africa's water sector: Phiri, Soweto's pre-paid meter protest" in Quarterly Bulletin of Third World Studies, 49(1) 2009 no. 391, p. 33, and TJOA, Interview 3: 2009.09.01.

116. GCOA, Interview 1: 2009.09.01.

117. TJOA, Interview 8: 2009.09.03.

118. GCOA, Interview 3: 2009.09.01; MIOA, Interview 8: 2009.09.02. 
firewood was scarce and expensive. ${ }^{119}$ This being so, there was good reason to believe that the public taps, especially those in Phelindaba, posed a potential health hazard to local residents. For example, according to a medical practitioner there was a possibility that Mycobacterium avium complex (MAC), an isolate in more than $95 \%$ of patients with AIDS, could be present in the stagnant water around the taps and in the plastic extension pipes. This bacterium multiplies in water with temperatures between $4^{\circ}$ and $66^{\circ} \mathrm{C} .{ }^{120}$ It was thought that this could well account for the high incidence of tuberculosis in Agisanang. ${ }^{121}$ Yet, local residents were not always aware of this health risk. Some observed that solids tended to settle in their water containers after 30 minutes. ${ }^{122}$ There seemed to be uncertainty whether or not this posed a potential health hazard.

\section{Sanitation}

In September 2009 residents of Sannieshof explained to the researchers that they feared the town's groundwater had become contaminated by sewage from the domestic septic tanks. They maintained that borehole water tended to smell of sewage. The current septic tank system was old and municipal officials did not readily call to clean the tanks. ${ }^{123}$ When they phoned the municipal offices to arrange for the service, officials took a long time to respond. Consequently, there were frequent overflows of sewerage tanks - with a bad smell in the residential and commercial areas of town. ${ }^{124}$ Some residents had resorted to paying a bribe of a R10 'tip' to municipal workers. They would then respond more promptly to requests for service delivery. Another alternative was to call and beg six or more times after which the municipality might perhaps respond. ${ }^{125}$ Another major concern was raw sewage overflowing from sewer pits; it flooded into the streets of the residential parts of town. When it rained the storm water carried the sewage into the Harts River. ${ }^{126}$ Moreover, residents of both Agisanang and Sannieshof were highly perturbed by reports of the municipal sewerage truck emptying its contents directly into the Harts River. ${ }^{127}$

In September 2009 the Sannieshof wastewater treatment works was in a bad state of repair. Raw sewage in the groundwater had allegedly contaminated the borehole water on a neighbouring farm. Laboratory tests showed high levels of Escherichia coli (E. coli) in the water. According to one respondent, the water smelt like sewerage; even the cattle were reluctant to drink it. ${ }^{128}$ Sannieshof's new wastewater treatment works was no longer working properly after 10 years of service. For a long time the plant had not been maintained correctly and because of rapid local population growth the plant was unable to process all the sewage. Storage dams became blocked

119. GCOA, Interview 19: 2009.09.03.

120. GCOA, Interview: PP Gouws (53), Vereeniging, 2009.10.19.

121. MSOA, Interview 6: 2009.09.02; MSOA, Interview 8: 2009.09.02; TJOA, Interview 3: 2009.09.01.

122. MSOA, Interview 2: 2009.09.01.

123. GCOA, Interview 14: 2009.09.03; GCOA, Interview 14: 2009.09.03; GCOA, Interview 17: 2009.09.03.

124. GCOA, Interview 7: 2009.09.01; GCOA, Interview 13: 2009.09.03.

125. GCOA, Interview 12: 2009.09.02; GCOA, Interview 13: 2009.09.03.

126. GCOA, Interview 7: 2009.09.01.

127. GCOA, Interview 1: 2009.09.01; GCOA, Interview 15: 2009.09.03.

128. GCOA, Interview 10: 2009.09.02. 
and frequently overflowed. ${ }^{129}$ Since about 2009 , because of maintenance problems raw sewage had been flowing into the Harts River. The staff had failed to report the matter to the director of technical services. ${ }^{130}$



Illustration $2 \mathrm{~A}$ hole dug in the ground that serves as toilet for residents of a dwelling in Agisanang Extension 3 (a.k.a. Phelindaba informal settlement). (Photograph: JWN Tempelhoff)

In response to the crisis the local municipality's technical department subsequently drew up a plan to address the problem:

- An emergency dam was built to prevent untreated sewage from flowing directly into the Harts River;

- Two monitoring firms, chosen by the district council, were instructed to analyse the situation and give advice on how to resolve the matter;

- The septic tank system (in Sannieshof) needed to be replaced by a modern sewerage system. (In a previous budget funds were allocated for this project, but the money disappeared); $; 13$ and

- The town's informal settlements needed proper sewerage infrastructure. ${ }^{132}$

129. GCOA, Interview 11: 2009.09.02.

130. GCOA, Interview 11: 2009.09.02.

131. GCOA, Interview 12: 2009.09.02; GCOA, Interview 11: 2009.09.02.

132. GCOA, Interview 11: 2009.09.02. 




Illustration 3 A dilapidated municipal tractor that apparently frequently broke down, was used to take raw sewage to Sannieshof's wastewater treatment works. (Photograph C Gouws)

At the time of the research team's fieldwork not all residents of Sannieshof were convinced that the local municipality's rescue operation of the plant was the correct strategy to pursue. The sanitary conditions as far as the town's black residents were concerned, was horrendous. In Agisanang extensions 1 and 2, where sewerage infrastructure had been installed in the 1990s, there were regular blockages and leakages by September $2009 .{ }^{133}$ This caused raw sewage to overflow into the streets. ${ }^{134}$ Residents complained of disgusting smells prevailing throughout the township. ${ }^{135}$ Some were convinced that the new pipes installed were of inferior quality. They said that the workmanship was decidedly shoddy. The community had raised the matter with the municipality on several occasions but there was simply no response. Some residents argued that issues of water and sanitation were only raised at the funerals of prominent ANC, SACP and COSATU leaders. There were no formal meetings held where members of the community and representatives of the municipality could discuss community concerns. ${ }^{136}$ One resident commented:

133. MIOA, Interview 4: 2009-09-01.

134. MSOA, Interview 2: 2009.09.01; GCOA, Interview 5: 2009.09.01; MIOA, Interview 6: 2009.09.02.

135. GCOA, Interview 2: 2009.09.01.

136. MIOA, Interview 7: 2009.09.02. 
My sanitation does not work at all, due to regular water shut-downs of up to five days. It affects the sanitation processes. ${ }^{137}$

Youths interviewed, made the unfounded claim ${ }^{138}$ that

Small pipes are installed for black people who cannot afford toilet paper and instead use newspaper [this will obviously block the pipes]. ${ }^{139}$

The township sewage system was virtually always blocked. Residents told the researchers that when it rained raw sewage flowed into the river, causing pollution. ${ }^{140}$ According to a local medical practitioner familiar with conditions in the townships, children played in the streets where sewage spills were common. They tended to be particularly prone to contracting worms, parasitic infections ${ }^{141}$ and dermatitis. ${ }^{142}$ Agisanang Section 3 (Phelindaba), at the time of the research fieldwork, did not have proper sanitation. ${ }^{143}$ The municipality allowed people to build dwellings on stands without any infrastructure or services. ${ }^{144}$ For want of a better system residents built their own long drops. These leaked raw sewage into the groundwater and the pits were usually full. ${ }^{145}$ Some residents simply dug shallow holes in the ground. When they were full, the holes were covered with soil and new ones dug close by. Others tended to use the open spaces outside their residential stands. Alternatively they walked out into the open veld. ${ }^{146}$

Dangerous sanitary conditions prevailed in areas where large groups of people congregated on a regular basis. At a local crèche the staff and children resorted to using buckets when the water was shut down, otherwise the toilets became blocked. ${ }^{147}$ The prevailing conditions were described as 'terrible'. One local resident was of the opinion that the situation posed a serious health risk for the children. ${ }^{148}$ At the department of health's youth centre in Agisanang, the sewerage system was frequently blocked for a considerable period. Youths frequenting the centre had to use nearby open ground instead of the toilets. The matter had been reported to the municipality but there was no response. ${ }^{149}$ Local schools have water-borne sewerage systems but since installation the municipality has not serviced them. Schools regularly experience blockages because of

137. MIOA, Interview 4: 2009.09.01; GCOA, Interview 8: 2009.09.01.

138. Both council officials and members of SIBU deny this claim categorically. Personal disclosures were made to members of the research team to this effect on 2009.11.12. It was described as a 'township myth'.

139. MSOA, Interview 10: 2009.09.02.

140. MIOA, Interview 2: 2009.09.01; MIOA, Interview 6: 2009.09.02.

141. GCOA, Interview 13: 2009.09.03.

142. GCOA, Interview 1: 2009.09.01.

143. GCOA, Interview 3: 2009.09.01; TJOA, Interview 3: 2009.09.01.

144. GCOA, Interview 8: 2009.09.01.

145. GCOA, Interview 3: 2009.09.01.

146. TJOA, Interview 7: 2009.09.03.

147. MSOA, Interview 7: 2009.09.02.

148. MSOA, Interview 7: 2009.09.02.

149. MIOA, Interview 6: 2009.09.02. 
unexpected water shutdowns. They complained that when the water supply was restored, the pressure in the sewage pipes caused blockages. ${ }^{150}$

Sanitary conditions in the residential area of Sannieshof were reported to be better. This was a direct result of the residents' initiative to take control and assert pressure on the municipality to attend to problems. If there were no prompt and satisfactory response, SIBU's members would take steps to personally address the situation.

\section{Theoretical perspectives: political culture, socialisation and happiness}

In order to come to an understanding of the dynamics of the water situation in Sannieshof and environs, the research team undertook an examination of the theoretical underpinnings of political culture, socialisation and happiness. Each of these issues will be discussed from a theoretical perspective and then some of the information collected in the interviews will be integrated into the discussion.

\section{Political culture and socialisation}

This refers to the cultural values that govern political behaviour, and entails the collective political attitudes of the population. ${ }^{151}$ Political culture is an essential part of the process of nation building and democratisation that promotes an active citizenry in local governance. ${ }^{152}$ According to Almond and Verba, democracy requires the existence of a civic culture, ${ }^{153}$ the tenets of which are the product of political socialisation. ${ }^{154}$ Furthermore, Pye believes that socialisation determines culture within society and that culture shapes the personality of the society towards political institutions. ${ }^{155}$

Sannieshof tends to have a fragmented political culture - a phenomenon that has been defined in theoretical context by Kamrava. ${ }^{156}$ It is a situation in which residents typically embrace a subjective and participant political culture. However, in the case of Sannieshof there is a clear divide - along racial lines. The black communities in the townships of Agisanang and Phelindaba have a culture of subjectivity; they exhibit a blind obedience to administrative output, directives and a one-way flow of information. These people, in terms of the theoretical arguments and the description of local conditions outlined thus far, have become discouraged; they feel powerless

150. MIOA, Interview 3: 2009.09.01.

151. M Kamrava, Politics and society in the developing world, (Second edition, Routledge, London, 2000), pp. $120,121$.

152. Ibid., pp. 120-122.

153. LW Pye, "Political culture revisited", International Society of Political Psychology, 12(3) September 1991. p. 499.

154. M Kamrava, Politics and society in the developing world, pp. 120-121.

155. LW Pye, "Political culture revisited", International Society of Political Psychology, 12(3) September 1991. p. 494.

156. M Kamrava, Politics and society in the developing world, pp. 120, 121, 125. 
and excluded from the political process. In contrast, the white population in the town of Sannieshof is a participant culture where people play an essentially active role in the political process - either as supporters or opponents. The local black population responded differently. According to Hanyeke 'poor communication discourages public participation'. ${ }^{157}$ This was evident in the informal settlement area of Phelindaba adjacent to Agisanang, where the lack of communication gave rise to frustration amongst residents. In September 2009 they spoke of marginalisation. One respondent explained:

These people [political candidates in the election of 2009] were able to visit us when campaigning for our votes. Now that they are in power, they forget about us. ${ }^{158}$

Another said:

They hold meetings in the old township, nothing is said of us. ${ }^{159}$

Members of the community of Phelindaba felt distanced from the political processes in their environs. They saw themselves as a forgotten people. Members of the research team came to the conclusion that the political leaders dismissed the support of the people in the informal settlement as dispensable. After all, Mattes and Christie argue:

People concerned with meeting basic needs on a daily basis may be expected to have less time to devote to democratic participation, and less reason to care about the survival of democracy. ${ }^{160}$

The people who show an interest in politics, but are ignored, have the potential to become the nucleus of violent protests over service delivery. Tadesse et al, suggest that

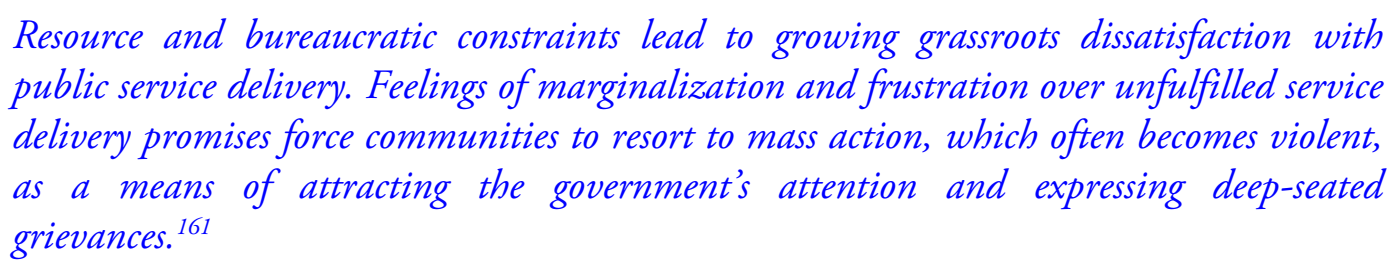

At the time of the research fieldwork in September 2009, the indications were that the local black population was fairly docile. Chances of civil unrest, similar to that taking place elsewhere in the country appeared to be slim. However, the local demographics suggested that conditions could change in the near future.

157. BR Hanyane, "The establishment, role and contribution of the South African National Civics Association (SANCO) in Soweto: a question of civic interest", (M.A. UNISA, 2002), p. 39.

158. MIOA, Interview 2: 2009.09.01; Interview 3: 2009.09.01; Interview 1: 2009.09.01.

159. MIOA, Interview 7: 2009.09.02.

160. R Mattes and J Christie, "Personal versus collective quality of life and South Africans' evaluations of democratic government" in Social Indicators Research, 41(1/3) July 1997, p. 208.

161. E Tadesse, et al. The people shall govern: A research report on public participation in policy processes. Centre for the study of Violence and Reconciliation (CSVR) and Action for Conflict Transformation (ACTION). February 2006, pp. 4, 9 at http://www.gsdrc.org/goldisplayetype=Documenterid=2012 (Internet accessed 2009.09.11).

TD, 6(1), July 2010, pp. 25- 56 
Youth groups and sports clubs in Agisanang act as vital socialisation agents. Given the fact that more than 72 per cent of Tswaing's population is below the age of 35 years, ${ }^{162}$ it is important to take note of the youth. The cultural institutions supported by the youth (such as sporting activities) suggest that they are apathetic towards local politics. It was significant that by September 2009, municipal sporting facilities - a strong cultural instrument for bringing people together - had fallen into a state of disrepair despite the presence of a very passionate and talented youth base, eager to be kept busy with constructive social sporting acivities. Young people who were interviewed said that local municipal officials took no interest at all in their wellbeing. ${ }^{163}$ They felt that the municipality should invest in their potential and promote sports as an instrument to alleviate the negative orientation they have towards local government. This could encourage them to participate actively in matters of local governance. As a result of the ratepayers' initiative to set things right, the residents of Sannieshof took matters into their own hands and started maintaining the bowling green, tennis courts and the golf course. ${ }^{164}$ Given the fact that their demographic profile tended to be representative of an ageing population they did not require of the municipality to create opportunities for youth activities. Instead they formed themselves into a self-help institution to take care of the sporting commons. This is but one striking feature of the contrasting perspectives local residents have of appropriate cultural political responses to addressing the problems they face. Another dimension also became apparent in respect of the environment.

Sannieshof's residents took an environmental approach, one they perceived as a more constructive way of dealing with the local water problems. In contrast, in the informal settlement of Phelindaba, residents had little concern for the environment. For them there were other more important issues. One explained:

\section{Our people are not concerned with the condition of the river, the environment, and local democratic processes. They are hungry and trying to make ends meet. There is just too much poverty in our area. The fact that councillors make empty promises does not assist our people in any way. ${ }^{165}$}

The research team saw such comments as significant - especially when public opinion is seen against the backdrop of the government's discourse with its people. According to the draft document on public policy the government is committed to a form of consultation and participation, which is genuinely empowering. It should not merely be token consultation or manipulation. The government wants to improve the accountability of ward and municipal structures; they must be responsive to the communities they serve. ${ }^{166}$ However, this notion, in September 2009 seemed to have been disregarded by the municipality and the ward councillors

162. Tswaing Local Municipality, Amended integrated development plan 2007-2011. Resolution No. 028/03/2009/10, p. 11.

163. MSOA, Interview 10: 2009.09.02.

164. VGOA, Interview 6: 2009.09.02.

165. MIOA, Interview 7: 2009.09.02.

166. DPLG 2005: 1 Draft national policy framework on public participation: Rooting government amongst the people. Public Participation and Empowerment Chief Directorate Free Basic Services and Infrastructure Branch, at http://www.thedplg.gov.za/index.php?option=com docman\&task=doc view\&gid=23 (Internet accessed 2009.09.18). 
of Tswaing Local Municipality, responsible for Sannieshof and its surroundings. There were no indications of community-based organisational activities. The local municipality did not effectively support even the municipal youth centre, representative of a meaningful sector of the local community. ${ }^{167}$ The state of affairs was that of a community which had lost trust in its ward councillors and the local municipality as a whole. Giddens suggests that diminished trust in politicians and other figures of authority are indications of general social apathy. ${ }^{168}$ In September 2009 this type of situation was evident in both Agisanang and Phelindaba. Township residents felt that most officials and politicians merely imposed decisions upon them. ${ }^{169}$ This, according to Hanyane, is the result of a lack of consultation by government officials with community members. It typically encourages a lack of participation in ward committee meetings, and public meetings summoned by the local government. ${ }^{170}$

The apparent absence of potential benefits for attending meetings further contributed to a lack of participation by the public. The community of Sannieshof and surroundings blamed public officials who frequently made promises that were never fulfilled. ${ }^{171}$ Instead of a much talked about consultation process, public officials hijacked, for example, the funeral services of elite politicians. They used these events as a platform for discourses on community problems and how these could be resolved. ${ }^{172}$ In other instances a consultation/public meeting often coincided with a party (celebration) of sorts. The politician would then tell the public what was 'already in the pipeline'. The public input at such meetings was seldom taken into consideration. One respondent used the example of the construction of a local community hall. ${ }^{173}$ In his opinion, if the people had been asked for their view the local municipality would have been told that the public needed water more urgently than a new hall. By September 2009 the hall was standing un-used. It had become the 'mansion' of a local hermit. ${ }^{174}$ No one in the township seemed to care about it. This case study is typical of what Tadesse et al, are driving at when they write that:

\section{[I]n the absence of meaningful public participation, the effectiveness of governance to deliver the required public services and safeguard human security is severely limited. ${ }^{175}$}

Proper consultation procedures would probably go a long way towards restoring the trust and effective support of civil society in the local authority. A concerted initiative should be launched to encourage the youth to be aware of local government issues and become actively involved.

167. MSOA, Interview 6: 2009.09.02.

168. A Giddens, The third way: the renewal of social democracy, (Polity Press, Malden, Mass, 1999), p. 80.

169. MIOA, Interview 1: 2009.09.01.

170 . BR Hanyane, "The establishment, role and contribution of the South African National Civics Association (SANCO) in Soweto: a question of civic interest", p. 37.

171. MSOA, Interview 3: 2009.09.01; Interview 10: 2009.09.02.

172. MIOA, Interview 7: 2009.09.02.

173. MIOA, Interview 1: 2009.09.01.

174. MSOA, Interview 3: 2009.09.01.

175. E Tadesse, et al. The people shall govern: A research report on public participation in policy processes. Centre for the study of Violence and Reconciliation (CSVR) and Action for Conflict Transformation (ACTION). February 2006, p. 8 at http://www.gsdrc.org/goldisplay\&type=Documenterid=2012 (Internet accessed 2009.09.11). 
They have to feel convinced that it is in their interest to be participants in the development of the local community. It is imperative that political office bearers educate the public on the significance of public participation. ${ }^{176}$ The political leaders must step up their public consultation. If they fail to do so the political culture in the Sannieshof/Tswaing community will not improve; people need to be involved, to regard themselves as primary role players. According to Giddens, they have to be 'working in partnership with government to foster community renewal and development' on the local level. ${ }^{177}$ They must be able to influence public decisions. Public participation is essential to equip citizens with the

\section{critical capacities to weigh evidence before speaking and acting, to build on and to extend radically to young people the best in existing traditions of community involvement and public service, and to make them individually confident in finding new forms of involvement and action among themselves. ${ }^{178}$}

Such participation is an important move to avoid the continuation of the current epidemic of violent service delivery protests raging in many parts of South Africa. An active citizenry, as seen through civic organisations such as SIBU, is crucial for strengthening democracy. ${ }^{179}$ It contributes towards improving service delivery and environmental livelihoods within the Sannieshof community. ${ }^{180}$ Tadesse et al regard participation as proactive and critical - not merely reactively supportive of the status quo. ${ }^{181}$ SIBU is proactive in the sense that members have taken it upon themselves as members of a concerned civil society, to remedy that which the local government (plagued by mismanagement and incapacity) has been unable to do. Rather than burning the municipal buildings or reacting apathetically by withholding their rate payments, they have instead created a healthy environment by cleaning the streets. ${ }^{182}$ They have amassed resources to invest in something tangible for the benefit of all the residents. In so doing they have restored dignity and secured a sense of human rights by providing water to a community 'forgotten/ignored' by politicians.

While there are frustrated communities throughout South Africa that respond violently against poor service delivery, people in Agisanang and Phelindaba reacted otherwise; they fell into a state of apathy. This is a scary social condition considering Ichilov's assertion that a healthy democracy depends on an active citizenry. Apathy is cause for concern, even alarm. ${ }^{183}$ It is of concern

176. BR Hanyane, "The establishment, role, and contribution of the South African National Civics Association (SANCO) in Soweto: a question of civic interest", p. 1.

177. A Giddens, The third way: the renewal of social democracy, (Polity Press, Malden, Mass, 1999), pp. 69, 79.

178. Bernard Crick, as quoted in H Haste, "Constructing the citizen" in Political Psychology, 25(3), June 2004, p. 427 (413-439),

179. BR Hanyane, "The establishment, role, and contribution of the South African National Civics Association", p. 1.

180. H Haste, "Constructing the citizen" in Political Psychology, 25(3), June 204, p. 427

181. E Tadesse, et al. The people shall govern: A research report on public participation in policy processes. Centre for the study of Violence and Reconciliation (CSVR) and Action for Conflict Transformation (ACTION). February 2006, p. 6 (Internet accessed 2009.09.11).

182. MSOA, Interview 2: 2009.09.01.

183. H Haste, “Constructing the citizen” in Political Psychology, 25(3), June 204, p. 426. 
because one cannot really fathom the true psyche of such a community. Should one expect Agisanang and Phelindaba to be the next site of violent service delivery protests in the immediate future? It is difficult to say. 'We have been wounded in the mind'184 is a phrase used by both the youth and adults when describing the dire situation in which Sannieshof s black townships find themselves. They are unable to mobilise with a common purpose to pressurise the local government to address their concerns. They are dependent on the state to solve their local problems. They ascribe their 'helpless' position to their poor economic standing and low level of education. Their [local] government has failed to 'deliver material improvements which will improve a perceived quality of life'. ${ }^{185}$ There have been no daily conversations on the community's affairs. Instead, community members have literally been socialised, or conditioned, to regard themselves as 'powerless' and unable to change the dictates of those in 'power' i.e. local government officials. This is a misplaced conception because 'no political agent is ever entirely powerful or powerless'. ${ }^{186}$ At the time of this study there was nobody of Carin Visser's calibre in the black community who aspired to come to the fore to represent the sentiments of other folk in the area. Those who tried to do so would typically be enticed away by existing political opportunities to position themselves for a lucrative political appointment. ${ }^{187}$ Any action that aimed at challenging the existing local political status quo was simply ignored or suppressed. Those in power encouraged passive adherence. ${ }^{188}$ This in turn increased the potential for totalitarian authority.

Sannieshof's ratepayers responded differently. They were driven by what they perceived as incompetent local government. This threatened their business interests and the wellbeing of the community. Consequently they made their voices heard. The researchers were convinced that SIBU's actions were in part due to their education and deep understanding of how the democratic system should operate. They were also able to establish an area of common interest to challenge or change existing conditions. Their willingness to co-operate, despite their diverse political and religious affiliations, enabled them to work together. The only problem SIBU faced was the racial composition of its membership. It was seen as a predominantly white movement. Blacks were critical of its purpose. They claimed that it only represented the white community. They were also of the opinion that SIBU used the poor black community to get sympathy from the media. ${ }^{189}$ The absence of a significant black membership in the organisation encouraged the local government to continue their criticism of SIBU's endeavour by projecting it as acting in open defiance of the rule of law. They even went so far as to suggest that SIBU was a rightwing initiative pushing a political agenda to discredit the ruling party. Following the tenets of 'third

184. MIOA, Interview 7: 2009.09.02.

185. R Mattes and J Christie, "Personal versus collective quality of life and South Africans' evaluations of democratic government" in Social Indicators Research, 41(1/3) July 1997, p. 206.

186. P Nesbitt-Larking, "Methodological Notes on the Study of Political Culture" in Political Psychology, 13(1) March 1992, p. 80.

187. R Mattes and J Christie, "Personal versus collective quality of life and South Africans' evaluations of democratic government" in Social Indicators Research, 41(1/3) July 1997, p. 206.

188. A Botha, "Political dissent and terrorism in southern Africa" in Institute for Security Studies, Paper 90 August 2004, p. 4

189. MIOA, Interview 1: 2009.09.01. 
way' politics advocated by Giddens, ${ }^{190}$ the missing link in Sannieshof is that residents of the area should transcend existing cultural and racial barriers. They need to move towards the common goal of protecting human rights and dignified living conditions. Improving the natural environment in Sannieshof and the greater Tswaing municipal area for the benefit of all who live there may be one way of doing it. Tadesse et al, maintain that

\section{(C)ontext specific participatory governance systems and public participation mechanisms will facilitate better informed policy decisions; increase the responsiveness and accountability of government departments; improve public service delivery and human security; and reduce the need for the public to resort to violence... ${ }^{191}$}

Working together, they can do more

$$
\begin{aligned}
& \text { given that the greater proportion of the population the group represents, the greater its } \\
& \text { impact. }{ }^{192}
\end{aligned}
$$

However, this sense of collaborative effort and togetherness will require a concerted effort from all groupings in the community. They have to be inspired in their attempts to create a sense of local solidarity and civic commitment to promote a better livelihood for all the residents of Sannieshof and its surroundings.

\section{Happiness?}

At the beginning of this article it was claimed that the wave of violent service delivery protests South Africa experienced could be symptomatic of a society that was severely depressed and literally unhappy. Consequently, with a view to finding solutions to the current predicament, the research team decided to find out how people in the vicinity of Sannieshof and surroundings felt about happiness. But what is happiness? In modern day society, the concept of happiness is an indefinable, subjective notion, ${ }^{193}$ the experience of which is grounded in hedonism, ${ }^{194}$ desire theory ${ }^{195}$ and the objective list theory. ${ }^{196}$ The hedonistic approach focuses on attaining pleasure

190. A Giddens, The third way: the renewal of Social Democracy, (Polity Press, Malden, Mass, 1999), pp. 69-70.

191. E Tadesse, et al. The people shall govern: A research report on public participation in policy processes. Centre for the study of Violence and Reconciliation (CSVR) and Action for Conflict Transformation (ACTION). February 2006, p. 3.

192. A Botha, "Political dissent and terrorism in southern Africa" in Institute for Security Studies, Paper 90 August 2004, p. 4.

193. M Seligman, Authentic happiness, (Free Press, New York, 2002).

194. R Nelson-Jones, Cognitive humanistic therapy: Buddhism, Christianity and being fully human, (Sage Publications, London 2004); RM Ryan, and EL Deci, "On happiness and human potentials: A review of research on hedonic and eudaimonic well-being" in Annual Review of Psychology, 52, 2001, pp. 141-166; MJ Sirgy, and J Wu, "The pleasant life, the engaged life, and the meaningful life: What about the balanced life?" in Journal of Happiness Studies, 10, 2009, pp. 183-196.

195. J Griffin, Well-being: Its meaning, measurement, and moral importance, (Clarendon Press, Oxford, 1986); MEP Seligman, and E Royzman, "Happiness: the three traditional theories" 2003 at http://www.authentichappiness.sas.upenn.edu/newsletter.aspx?id=49 (Internet accessed 2009.04.04).

196. M Nussbaum, "Human functioning and social justice: in defense of Aristotelian essentialism" in Political Theory, 20, 1992, pp. 202-246. 
and avoiding displeasure. ${ }^{197}$ Desire theory is concerned with the process of gratification and the realisation of desires which then contributes to happiness regardless of the amount of pleasure or displeasure derived from it. ${ }^{198}$ On the other hand, objective list theory maintains that happiness is derived from achieving goals, which enables one to derive meaning from events. ${ }^{199}$ Peterson, Nansook and Seligman proposed an integrated model for happiness flowing from these approaches. ${ }^{200}$

Peterson et al suggest three routes to happiness namely pleasure, meaning and flow. ${ }^{201}$ The first route to happiness entails the never-ending pursuit of pleasure in one's life. According to Seligman, Parks, and Steen, focusing on increasing pleasure in order to enhance happiness will not have a lasting influence on happiness, because people have a genetically determined set-point for pleasure, and because they quickly adapt to pleasure. ${ }^{202}$ The second route to happiness is through pursuing gratification, which engages people fully in activities. Flow requires that individuals apply their strengths, such as kindness and creativity. The third route to happiness is to use strengths to belong to and in service of something larger than the self, which give life meaning. It is evident that interventions that target engagement and meaning seem most fruitful when linked with the pleasure flowing from them. The experience of pleasure and flow are

197. R Nelson-Jones, Cognitive humanistic therapy: Buddhism, Christianity and being fully human, (Sage Publications, London 2004); RM Ryan, and EL Deci, "On happiness and human potentials: A review of research on hedonic and eudaimonic well-being" in Annual Review of Psychology, 52, 2001, pp. 141-166; MJ Sirgy, and J Wu, "The pleasant life, the engaged life, and the meaningful life: What about the balanced life?" in Journal of Happiness Studies, 10, 2009, pp. 183-196.

198. J Griffin, Well-being: Its meaning, measurement, and moral importance, (Clarendon Press, Oxford, 1986); MEP Seligman, and E Royzman, "Happiness: the three traditional theories" 2003 at http://www.authentichappiness.sas.upenn.edu/newsletter.aspx?id=49 (Internet accessed 2009.04.04).

199. M Nussbaum, "Human functioning and social justice: in defense of Aristotelian essentialism" in Political Theory, 20, 1992, pp. 202-246; MJ Sirgy, and J Wu, "The pleasant life, the engaged life, and the meaningful life: What about the balanced life?” in Journal of Happiness Studies, 10, 2009, pp. 183-196.

200 . C Peterson, P Nansook, and MEP Seligman, "Orientations to happiness and life satisfaction: the full life versus the empty life" in Journal of Happiness Studies, 6, 2005, pp. 25-41.

201. C Peterson, N Park and MEP Seligman, "Orientations to happiness and life satisfaction: The full life versus the empty life" in Journal of Happiness Studies, 6, 2005, pp. 25-41.

202. MEP Seligman, A Parks, A. and T Steen, “A balanced psychology and a full life” in The Royal Society, Philosophical Transactions: Biological Sciences, 359, 2004, pp. 1379-1381. 
subjective, ${ }^{203}$ whereas meaning is partly objective and rooted in a sense of purpose, which goes beyond life's pleasures and desires. ${ }^{204}$

In the current study, researchers asked all respondents, as an aside, to state what would really make them happy. Both white and black residents wanted access to proper water supply and sanitation services. ${ }^{205}$ The whites specifically singled out an orderly society with proper municipal services. ${ }^{206}$ Both whites and blacks wanted families to live together/be united. ${ }^{207}$ Blacks indicated that they would be very happy if they could have houses like the whites. ${ }^{208}$ Running water and flushing toilets were seen as integral to the luxury that white residents of the town enjoyed. Black people also said that finding relief from unemployment would make them happy. Experiencing poverty and related suffering made them unhappy. ${ }^{209} \mathrm{~A}$ female respondent indicated that she would be happy if Carin Visser's action against Tswaing was successful. ${ }^{210}$ A male respondent explained that he would be happy if tourists visited the Barberspan region. ${ }^{211}$

With the exception of one respondent, the environment did not feature very high at all on the list of priorities, when it came to locating a sense of happiness. Therefore it could perhaps be argued that black respondents did not care much for the environmental discourse of SIBU. They saw SIBU's awareness of the environment as a 'cosmetic issue' that was less significant, for example, than poverty and unemployment. Seligman suggests that situational variables only contribute to $10 \%$ of an individual's overall level of happiness. Situational variables $(10 \%)$ as well as a genetic set point (50\%), account for $60 \%$ of a person's total level of happiness. ${ }^{212}$

203. R Nelson-Jones, Cognitive humanistic therapy: Buddhism, Christianity and being fully human, (Sage Publications, London 2004); RM Ryan, and EL Deci, "On happiness and human potentials: A review of research on hedonic and eudaimonic well-being" in Annual Review of Psychology, 52, 2001, pp. 141-166; MJ Sirgy, and J Wu, "The pleasant life, the engaged life, and the meaningful life: What about the balanced life?" in Journal of Happiness Studies, 10, 2009, pp. 183-196; MEP Seligman, and E Royzman, "Happiness: the three traditional theories" 2003 at http://www.authentichappiness.sas.upenn.edu/newsletter.aspx?id=49 (Internet accessed 2009.04.04); M Nussbaum, "Human functioning and social justice: in defense of Aristotelian essentialism" in Political Theory, 20, 1992, pp. 202-246.

204. D May, R Gilson and L Harter, "The psychological conditions of meaningfulness, safety and availability and the engagement of the human spirit at work" in Journal of Occupational and Organizational Psychology, 77,2004, pp. 11-37; C Peterson, N Park and MEP Seligman, "Orientations to happiness and life satisfaction: The full life versus the empty life” in Journal of Happiness Studies, 6, 2005, pp. 25-41; M Seligman, Authentic happiness, (Free Press, New York, 2002); A Wrzesniewski, C McCauley, P Rozin and B Schwartz, "Jobs, careers and callings: people's relations to their work" in Journal of Research in Personality, 31, 1997, pp. 21-33.

205. MSOA, Interview 5: 2009.09.01; TJOA, Interview 6: 2009.09.02; MSOA, Interview 3:2009.09.01

206. VGOA, Interview 1: 2009.09.01; TJOA, Interview 2: 2009.09.01; TJOA, Interview 6: 2009.09.02; MIOA, Interview 1: 2009.09.01; VGOA, Interviews 4 and 5: 2009.09.02.

207. VGOA, Interview 1: 2009.09.01; TJOA, Interview 5: 2009.09.01;

208. GCOA, Interview 2: 2009.09.01, GCOA, Interview 3: 2009.09.01.

209 GCOA, Interview 6: 2009.09.01.

210. TJOA Interview 1: 2009.09.01.

211. TJOA, Interview 10: 2009.09.04.

212. M Seligman, Authentic happiness, (Free Press, New York, 2002). 
Therefore, $40 \%$ of an individual's total level of happiness is under his/her direct control. ${ }^{213}$ Many of the respondents interviewed felt that there was a direct relationship between improvements in the environment and their overall level of happiness but research suggests that happiness derived from such changes is temporary in nature. ${ }^{214}$ The key to happiness lies not in changing our environment, but rather in changing our daily intentional activity. ${ }^{215}$ The focus should lie on facilitating the respondents through a process of individuation, whereby they are able to effectively utilise their limited resources. In order to re-establish a sense of sustainable happiness a sense of meaning has to be instilled in their lives. ${ }^{216}$ Building on meaning should facilitate the development of flow, ${ }^{217}$ which in turn contributes to the sustainability of the emotion. It is evident that intervention is needed in order to enhance the quality of the respondents' lives in Sannieshof. This inherent need is not just confined to Sannieshof, but also to the larger population. It is the opinion of the researchers that the basic need for happiness should be manifested in legislation, where happiness becomes a right rather than a luxury.

Perhaps the willingness to live without this basic right to experience a sense of happiness is symptomatic of present-day South African society. For so many years there was a struggle in the country aimed at contesting the racial bias of those in control of the country's government. The trauma of the freedom struggle, which ended in 1994, has left many scars. It left little space for a sense of happiness. In no document of state is this more evident than in the Constitution of the Republic of South Africa Act, No 36 of 1996. In contrast with the constitution of the United States of America, which explicitly stipulates that government is for the benefit of the people and should promote the right for all to pursue happiness and a sense of safety, ${ }^{218}$ there is no reference in the South African constitution to happiness. The Bill of Rights, a centrepiece of the constitution, embraces the most worthy elements of what it means to be part of our society, but alas, happiness is not one of those rights. The closest that we in South Africa, come to enjoy happiness as a constitutional right, is a sense of 'well-being'. There are three references to 'wellbeing' in the constitution. Section 24a stipulates that everyone has the right to an environment that is not harmful to their well-being. ${ }^{219}$ Section $28(\mathrm{f}) 1$ addresses children's rights. They should not perform work that is inappropriate to their age, or find themselves in circumstances that place their well-being at risk. ${ }^{220}$ The final reference to well-being is in Schedule 2 where in the inaugural oath, the president gives the undertaking to devote himself to the well-being of the

\section{Ibid.}

214. Ibid.; MEP Seligman, A Parks, A. and T Steen, "A balanced psychology and a full life" in The Royal Society, Philosophical Transactions: Biological Sciences, 359, 2004, pp. 1379-1381.

215. M Seligman, Authentic happiness, (Free Press, New York, 2002); MEP Seligman, "Positive health" in Applied Psychology: An International Review, 57, 2008, pp. 3-18.

216. M Seligman, Authentic happiness, (Free Press, New York, 2002).

217. D May, R Gilson and L Harter, "The psychological conditions of meaningfulness, safety and availability and the engagement of the human spirit at work" in Journal of Occupational and Organizational Psychology, 77, 2004, pp. 11-37.

218. DM McMahon, Happiness: a history, (Grove Press, New York, 2005), p. 318.

219. Section 24a in Schedule 2: Oaths and solemn affirmations Constitution of the Republic of South Africa Act, 108 of 1996 , in p. 1251.

220. Section 28(f) ii in RSA, Constitution of the Republic of South Africa Act, 108 of 1996, in p. 1255. 
country and all who live in it. ${ }^{221}$ Perhaps the absence of a very basic sense of happiness is a significant shortcoming in the constitution of the country - and in the aspirations of its people. Areas such as Sannieshof, where rural South Africans lead lives that stand out for their abject poverty, are a case in point. Circumstances of unemployment, inferior water service delivery, and limited prospects of better conditions in the foreseeable future, clearly make for a sense of unhappiness.

\section{Conclusion}

By the beginning of 2010, when the report of this investigation was in the final phase of completion, the steps taken by SIBU had not yet led to major changes in the lives of local residents. The municipal authority had not taken appropriate steps to address residents' grievances. There were some staff changes at Tswaing Local Municipality. Carin Visser and the management committee of SIBU continued to run a municipality within a municipality. The apparent dichotomy in support for SIBU's efforts suggested that local patriotism was still shaped by subjective forces reminiscent of the country's racial past. The polarisation in the local community remained deep. It affected society in a variety of ways and made it difficult to come to a clear and uncomplicated understanding of what was right and what was wrong. For example, the fact that some people simply did not pay for water, despite the fact that they were supporters of the local government, remained incomprehensible to the residents who boycotted service delivery on principled grounds. It was as if the wrongs of some were considered miniscule; and the wrongs of others were pardonable.

Over the long term the 'losers' could be identified on a number of levels. Firstly, those who were at the losing end were the poorest people in the community. Others still had resources, such as an income, to secure their resilience to inferior conditions. Secondly, the local authority had lost the support of local residents. Local officials were subject to suspicion for allegedly not having done their work. This would surely have had an effect on their personal dignity and their status in society. Thirdly, the hours spent by members of SIBU affected them in the sense that they were losers in terms of productivity. For many of them the work they were doing absorbed all of their spare time - and some of their working time.

Already towards the end of 2009 the South African government took a number of steps to set things right. Municipal government was one of the prime hotspots that received considerable government attention. Furthermore, government toned down its pre-election promises. What was required was the necessary political will to step in and begin providing adequate services in Sannieshof and its surroundings. The research team were of the opinion that it would make a substantial contribution to restoring local residents' sense of dignity and basic happiness.

221. Schedule 2: Oaths and solemn affirmations in RSA, Constitution of the Republic of South Africa Act, 108 of 1996 , in p. 1332. 